\title{
Lattice deformation of blue halite from Zechstein evaporite basin: Kłodawa Salt Mine, Central Poland
}

\author{
Sylwia M. Zelek • Katarzyna M. Stadnicka • \\ Tomasz Tobola $\cdot$ Lucyna Natkaniec-Nowak
}

Received: 2 August 2013 / Accepted: 5 March 2014 /Published online: 30 March 2014

(C) The Author(s) 2014. This article is published with open access at Springerlink.com

\begin{abstract}
Outcrops of natural blue and purple halite crystals have been found in Kłodawa (Poland) salt deposit originating from the Permian (Zechstein) salt formation within tectonic zones. Field works carried out on various levels of Kłodawa Salt Mine indicated differences both in intensity of the hue and in the size of the outcrops. Their occurrence was connected with the presence of epigenetic sediments rich in potassium. For the samples of blue halite, an optical anisotropy (birefringence) was observed for both standard mineralogical thin sections and thick plates, indicating a deviation from cubic symmetry. The blue colouration of the halites, described by ultraviolet-visible spectroscopy, is due to the presence of colour centres. The colour centres have been recently identified as: $\mathrm{F}, \mathrm{R}_{1}\left(\mathrm{~F}_{3}\right), \mathrm{R}_{2}\left(\mathrm{~F}_{3}\right), \mathrm{M}$ and plasmons (WesełuchaBirczyńska et al., Vib Spectrosc 60:124-128, 2012). The trace amount of impurities detected in the blue halites by means of scanning electron microscopy-energy dispersive X-ray spectroscopy and micro-X-ray fluorescence techniques were connected mainly with solid inclusions such as $\mathrm{K}_{x} \mathrm{Na}_{(1-x)} \mathrm{Cl}$, $\mathrm{KMgCl}_{3} \cdot 6 \mathrm{H}_{2} \mathrm{O}, \mathrm{KCl}$, orthorhombic sulphur, quartz and some other phases like pyrite. Crystallographic data obtained by X-
\end{abstract}

Editorial handling: A. Beran

Electronic supplementary material The online version of this article (doi:10.1007/s00710-014-0323-9) contains supplementary material, which is available to authorized users.

S. M. Zelek $(\bowtie) \cdot$ K. M. Stadnicka

Faculty of Chemistry, Jagiellonian University, ul. R. Ingardena 3, 30-060 Kraków, Poland

e-mail: zelek@geol.agh.edu.pl

S. M. Zelek $\cdot$ T. Toboła $\cdot$ L. Natkaniec-Nowak

Faculty of Geology, Geophysics and Environmental Protection, AGH University of Science and Technology, al. Mickiewicza 30, 30-059 Kraków, Poland ray diffraction experiments for the single crystals of the halite from Kłodawa with different saturation of blue or purple colours, as well as for natural colourless halite, revealed lowering of space-group symmetry to monoclinic, orthorhombic, trigonal, tetragonal or even triclinic systems while the space group typical for pure $\mathrm{NaCl}$ is $\mathrm{Fm}-3 m$.

\section{Introduction}

The blue colour of halite has been a subject of interest for many scientists. For example, there are several papers describing radiation damage of halite mainly for the usage of exploited salt mines as waste storages (Groote et al. 1991a,b, 1994; Seinen et al. 1992, 1994a,b; Weerkamp et al. 1994; den Hartog 1999; den Hartog and Vainshtein 1997; den Hartog et al. 2002, 2007). A review article by Sonnenfeld (1995) summarised the state of the art of the colour of rock salt. He pointed out factors responsible for the blue colour of halite crystals such as irradiation, soaking in sodium vapours, introducing impurities, inclusions of interstitial matter or structural defects in the crystal lattice. Blue halite occurs frequently in tectonically disturbed zones (tectonites) accompanied by sylvite veins (Davidge and Pratt 1963; Sonnenfeld 1995) and is considered as mineralogical rarity. Especially important for understanding the blue colouration of the halite from Kłodawa Salt Mine seems to be the report on blue halite by Howard and Kerr (1960). They had attributed the blue colouration of natural salt to the bombardment of gamma-ray from the potassium- 40 present in sylvite, which accompanied the halite bed. Blue and purple halite variations associated with potassium minerals are typical for Zechstein salt formation found in Kłodawa salt dome belonging to the Polish Zechstein Basin. 
The field work on all mining levels of Kłodawa Salt Mine, prior to laboratory experiments, were summarised by Toboła et al. (2007). In this paper, we present the results of investigations using optical microscopy, ultraviolet-visible (UV-vis) and Raman spectroscopies, scanning electron microscopy-energy dispersive X-ray spectroscopy (SEM-EDS) and crystal structure analyses of blue halite samples from Kłodawa Salt Mine.

\section{Geological setting}

The development of the Polish Zechstein Basin as the eastern part of the extensive Central European Basin was strongly controlled by faults that penetrate pre-Permian basement (Ziegler 1990). In the main depocentral axis of the Polish Basin, called the Mid-Polish Trough (MPT), the thickness of Permian sediments was completed with full development of the Zechstein evaporitic basin. These sediments were covered by thick Mesozoic and Quaternary beds. The geological features of MPT including tectonics, lithostratigraphy, correlation between tectonics of the basement and the development of MPT were described by numerous authors (e.g. Marek and Znosko 1972a, b; Wagner 1994; Dadlez et al. 1995; Wagner et al. 2002; Dadlez 2003; Krzywiec et al. 2003; Krzywiec 2006a, b; and references cited therein).

The Zechstein Basin was filled mostly with evaporites which are about $1,500 \mathrm{~m}$ thick (Wagner 1994). The lithostratigraphic classification of the basin sediments is based on evaporite sedimentary cycles. Four cyclothems were distinguished in the sediments. Three of them, PZ1, PZ2 and PZ3, were built of carbonates, anhydrites, rock-salt and potassium-magnesium salts. The cyclothems followed transgressive-regressive cycles of the Zechstein Sea. In the cyclothem PZ4, five subcyclothems (PZ4a-PZ4e) were distinguished. These subcyclothems were formed as a result of cyclic climatic changes (Wagner 1994; Pokorski and Wagner 1995) and showed terrigenous-evaporite sequences. These evaporites were covered by younger sedimentary rocks up to $8,000 \mathrm{~m}$ thick. The cover and active basement tectonics caused the development of numerous salt-bed structures, most of them associated with the MPT region (Krzywiec 2004a, 2006a, b; Ollier and Koziar 2007). Various aspects of the salt tectonics, such as the development of salts domes in relation to sub-Zechstein basement activity and the influence of the upraising salt structures on surrounding sediments, were analysed by many authors including recent papers by Krzywiec (2004a, b, 2006a, b) and references cited therein.

The Kłodawa salt dome is considered to be the largest diapir in Poland. It is located in Central Poland and belongs to Izbica Kujawska-Lęczyca salt ridge (Fig. 1a, acc. Garlicki and Szybist 1986). The Kłodawa dome, first discovered by gravimetric survey, was finally recognised by several boreholes made in the period of 1946-1950 (Werner et al. 1960). Studies of the diapir structure (Charysz 1973 and references cited therein; Burliga et al. 1995) indicated that it is about $26 \mathrm{~km}$ long, 0.5$2 \mathrm{~km}$ wide, elongated in NW-SE direction, and it reaches the depth of 7,000-8,000 m. The cross-section of the upper part of the diapir, shown in Fig. 1b (acc. Szybist 1995), revealed its asymmetric shape with the NE side dipping moderately (55$70^{\circ}$ ) eastward and with the SW side - almost vertical. The diapir, surrounded by deformed Mesozoic (Triassic-Jurassic) and partly Tertiary deposits, is covered by Tertiary and Quaternary sediments (Garlicki and Szybist 2008). The Kłodawa salt deposit is mainly composed of rocks which belong to fully developed PZ2-PZ4 cyclothems (Fig. 1c, acc. Garlicki and Szybist 1991). The lowermost unit (PZ1 cycle)-consisting of Kupferschiefer (T1), Zechstein Limestone (Ca1) and Lower Anhydrite (A1d) - is known exclusively as tectonically transported blocks (Werner et al. 1960; Burliga et al. 1995). The occurrence of the Oldest Halite (Na1) is questionable due to its petrological similarity to the Older Halite (Na2). In the case of the Older Halite (Na2), high purity of the rock salt and its common occurrence resulted in extensive exploitation of the deposit. The salts of PZ3-PZ4 cyclothems contain impurities, such as the laminae of anhydrite and the intercalations of $\mathrm{K}-\mathrm{Mg}$ minerals. In the lithological profile of these cycles, the clayey salts (zuber) are also present (Wagner 1994). Moreover, some kinds of pure salt such as lined salt (part of Na3a-PZ3) and pink salt (PZ4) have also been noticed (Charysz 1973; Garlicki 1993). In PZ3 cyclothem, a thick complex (20-30 m) of Younger Potash Salt (K3) was documented (Garlicki and Szybist 2008). The complex is built of kieseritic carnallite.

Due to salt strata deformations, the internal structure of the Kłodawa diapir was found to be complicated. The deformation effects, such as piercing of Older Halite (Na2) through Younger and Youngest Halite, tectonic tailing out and an occurrence of narrow folds with high amplitude, resulted from the various rheological properties of the rocks. The character and style of the deformations vary throughout the Kłodawa diapir (Tarka 1992). In general, two anticlines elongated in NW-SE direction were found to predominate in the SW and NE cross-sections of the diapir (Fig. 1b). The anticlines are separated by a deep central syncline composed of the youngest salt layers.

The blue halite outcrops are localised in KS39 chamber (on the level $600 \mathrm{~m}$ ) and in the ventilating gallery between chambers KS39 and KS38 (on the level $562 \mathrm{~m}$ ). Both outcrops are situated within the Older Halite (Na2). Another small outcrop was documented within the lower part of the Younger Halite (Na3a) on the level $600 \mathrm{~m}$. The close contact with sylvinite veins containing $\mathrm{KCl}$ and $\mathrm{NaCl}$ mixture is the common feature of all these associations (Natkaniec-Nowak and Toboła 2003; Toboła et al. 2007; Janiów et al. 2008). Substantial outcrop of blue halite was also found on the mining level $750 \mathrm{~m}$ near intersection of GTP2 and GTP2a galleries. In contrast to the associations mentioned above, in this outcrop, blue halite is accompanied by epigenetic carnallite. 
a

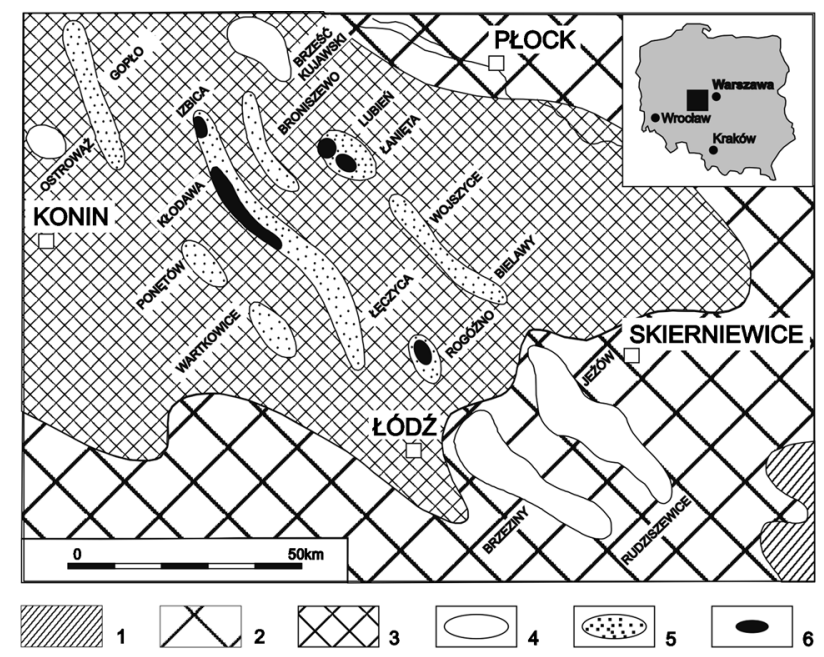

C

b

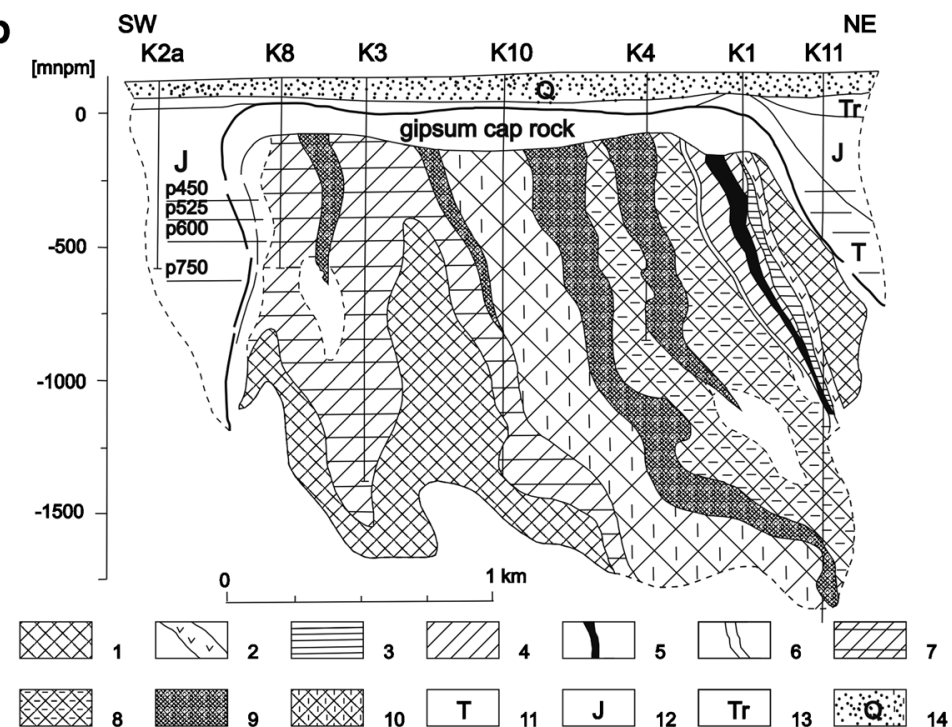

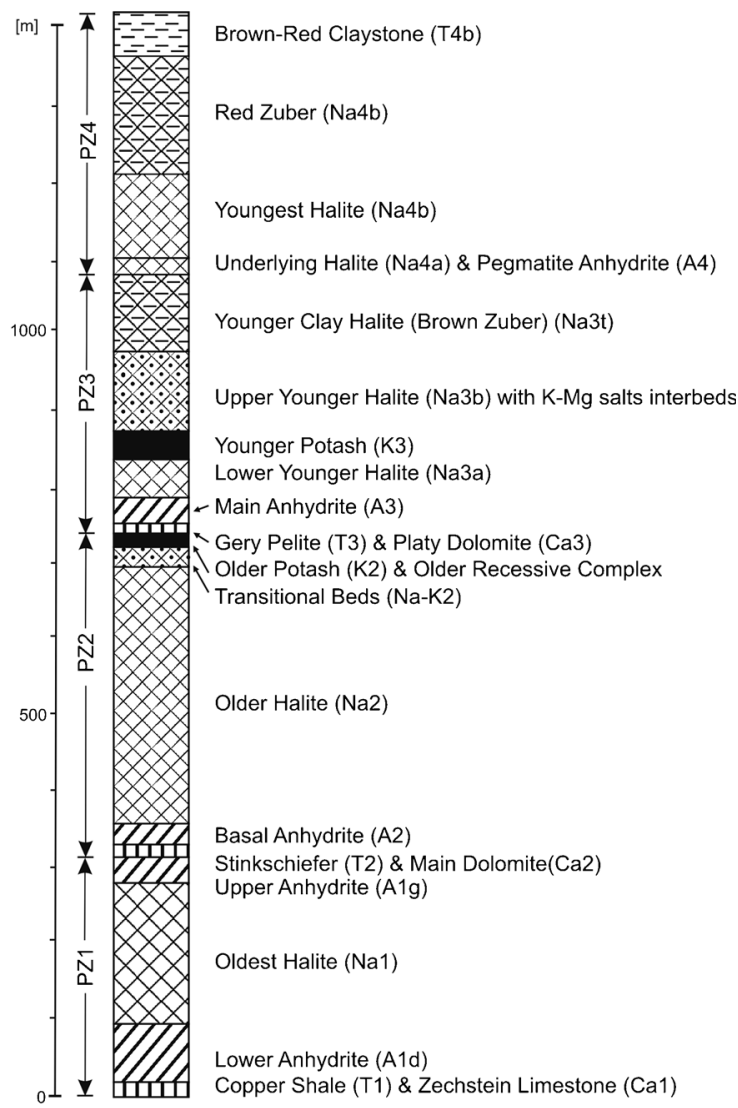

Fig. 1 a Part of Zechstein lithofacies map showing the localization of salt structures in the Łódź-Konin-Płock area (acc. Garlicki and Szybist 1986). 1 sulphate-carbonate-littoral facies, 2 chloride facies, 3 chloride facies with $\mathrm{K}-\mathrm{Mg}$ salts, 4 salt pillows and shafts, 5 salt domes structure partly breaking through the Mesozoic formation, 6 salt domes structure completely breaking through the Mesozoic formation. b Geological cross-section through the upper part of Kłodawa salt dome (acc. Szybist

\section{Samples and methods}

Blue and purple colours of halite have been frequently found in Kłodawa Salt Mine. The coloured halite was recognised on all mining levels (e.g. 450, 525, 562, 600, $750 \mathrm{~m}$ ). The bluehalite aggregates in the deposit were differentiated with respect to their size and the intensity of the hue. Contacts between the aggregates and surrounding sediments as well as the associations of accompanying minerals were diversified.

The specimens for our studies were sampled from KS39 chamber (on the level $600 \mathrm{~m}$ ), from the ventilating gallery between chambers KS39 and KS38 (on the level $562 \mathrm{~m}$ )-the
1995): 1 Older Halite, 2 Older Potassium Salt, 3 Grey Salt Clay and Main Anhydrite, 4 Younger Halite, 5 younger potassium salt (kieseritic carnallite), 6 carnallite-bearing association, 7 younger salts association, 8 Brown Zuber and clayey salts, 9 youngest halite (pink), 10 Red Zuber with clayey salts, 11 Triassic formation, 12 Jurassic formation, 13 Tertiary formation, 14 Quaternary formation. c Lithostratigraphic profile of Zechstein deposit in Kłodawa salt diapir (acc. Garlicki and Szybist 1991)

blue halite outcrops were accompanied by $\mathrm{KCl}$ veins - and from the level $750 \mathrm{~m}$ where they are accompanied by the epigenetic carnallite.

In prior of our studies, the contents of radioactive isotopes in the samples of sylvinite and blue halite from Kłodawa Salt Mine were investigated (Kozak, 2007, private information). The specific radioactivity of sylvinite and blue halite was found to be $13,930(630) \mathrm{Bq} / \mathrm{kg}(\mathrm{K}-40)$ and $1,582(72) \mathrm{Bq} / \mathrm{kg}$ (K-40), respectively, whereas there were no Ra-226 and Th228 isotopes. These values indicate the contents of $\mathrm{KCl}$ as $845(41) \mathrm{g}$ per $1,000 \mathrm{~g}$ of sylvinite and only $96(4) \mathrm{g} \mathrm{KCl}$ per $1,000 \mathrm{~g}$ of the blue halite, assuming $0.0117 \mathrm{~mol} \%$ of potassium-40 isotope in the samples of blue halite. 
Fig. 2 a Aggregates of the blue halite between sylvine vein (white salts) and halite (level $562 \mathrm{~m}$, the ventilation-cumulative gallery). b, $\mathbf{c}$ Parallel belts of blue colour in halite single crystals. d Side view of the halite crystal from c. e, $\mathbf{f}$ Irregular blue zones in single crystals of halite
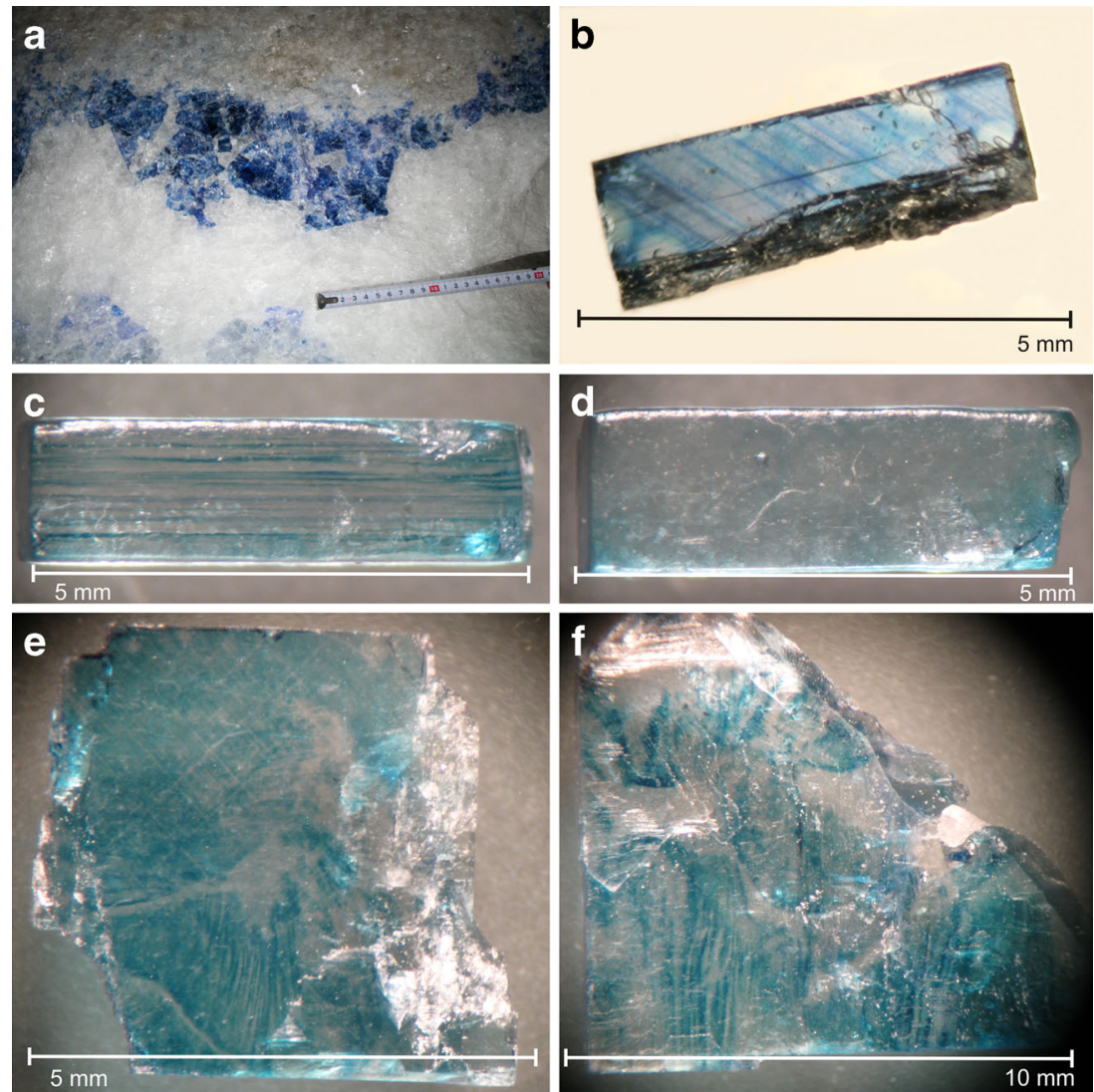

The saturation of blue hue in the halite aggregates was not homogeneous (Natkaniec-Nowak and Toboła 2003; Toboła et al. 2007; Janiów et al. 2008). It was found that intensive blue or even navy blue colour was characteristic for relatively big halite single crystals $2-6 \mathrm{~cm}$ in size (Fig. 2a). These crystals were mostly either euhedral or subhedral with clearly visible cleavage. In macroscopic observations, they displayed zones of dark blue hue or light blue hue alternate with colourless zones (Fig. 2b). Small crystals were usually either anhedral or subhedral. Their linear size ranged from $2 \mathrm{~mm}$ to about $2 \mathrm{~cm}$ but crystals above $5 \mathrm{~mm}$ predominated. The hue of these crystals was also diverse and changed from blue or light blue to light purple. Diversity of colour in single crystals was observed under stereoscopic microscope (Fig. 2c-f). Comparing Fig. $2 \mathrm{~b}-\mathrm{d}$, it is worth noting that the belts of blue colour in halite single crystals formed layers not always parallel to the cleavage planes and sometimes they might have irregular shapes (Fig. 2e, f).

The mineralogical analyses were performed on standard thin sections in polarised, transmitted light using an OLYMPUS BX51 microscope equipped with DP12 camera. Blue and purple samples of halite were characterised by reflection and absorption UV-vis spectra registered in the range of 200 $900 \mathrm{~nm}$ using Schimadzu 2101PC spectrophotometer equipped with ISR 240 device. Additionally, absorption spectra on small areas $\left(0.16 \mathrm{~mm}^{2}\right)$ were obtained using an Ocean Optics "diode array" PC2000 spectrometer. The halite samples of various saturation of blue colour were subjected SEMEDS analysis. Thick sections were prepared by cracking the selected single crystal along cleavage planes. Analyses were performed using FEI Quanta 200 FEG scanning microscope with an EDS detector. The system was operated at $15 \mathrm{kV}$ accelerating voltage under high vacuum. The different chemical compositions for the single-crystal halite fragments were also examined using the micro-X-ray fluorescence ( $\mu$-XRF) spectrometer Bruker M4 TORNADO equipped with an SDD detector. Operating parameters during the measurements were as follows: X-ray tube with $\mathrm{Rh}$ anode $30 \mathrm{~W}$ with working voltage of $50 \mathrm{kV}$, the intensity of $600 \mu \mathrm{A}$, spot diameter of $30 \mu \mathrm{m}$ (for line Mo-K), $100 \mathrm{~s}$ counting time per pixel; SDD detector: the surface area of $30 \mathrm{~mm}^{2}$, energy resolution $<145 \mathrm{eV}(\mathrm{Mn}-\mathrm{K})$. Single-crystal X-ray diffraction was performed for a set of crystals representing all types of observed halite hue: navy blue, pale blue, purple and natural colourless. X-ray intensity measurements of diffracted beams were carried out on a Nonius KappaCCD diffractometer and Agilent Technologies SuperNova, using graphite monochromated $\operatorname{MoK} \alpha$ radiation $(\lambda=$ $0.71073 \AA$ ) in both cases. 


\section{Results}

\section{Optical microscopy}

For optical microscopy investigation, the crystals representing all observed hue of blue-coloured halite with euhedral shape and cubic $\{100\}$ cleavage were sampled mainly from mining level $562 \mathrm{~m}$. Borders between single crystal domains were clear. However, sometimes, the spaces between single crystals were filled with fine crystallites showing optical properties similar to anhydrite. In some fragments of halite crystals, an optical anisotropy was observed under polarising microscopy, and the typical examples are shown in Fig. 3. Optical anisotropy was also observed in thick sections $(0.5 \mathrm{~mm})$ prepared for fluid inclusion analysis (Fig. 4a, b; compare WesełuchaBirczyńska et al. 2008). Observations under the transmittedlight microscope revealed that the blue halite contains many various solid-phase inclusions well separated from the halite matrix. The most frequent inclusions were those with the oval shape atypical for evaporates (Fig. 4a, c, d). These inclusions usually were birefringent except those of $\mathrm{KCl}$. The size of the inclusions ranged from a few dozen micrometres to few millimetres. Smaller inclusions were almost spherical (Fig. 4c), whereas the bigger ones displayed irregular contours (Fig. 4d). It is worth noting that around solid inclusions in blue halite the radial colourless areas, of $0.1-0.5 \mathrm{~mm}$ in thickness, were often observed (compare Figs. 2b, 3 and 4a, c, d). Most of the mineral phases of the solid inclusions in dark blue halite were characterised by corrosion of their borders and changes in optical properties. The results were confirmed by chemical analysis using $\mu$-XRF method for the solid inclusions and indicated the presence of following elements in trace amount: $\mathrm{Br}, \mathrm{Ca}, \mathrm{Cl}, \mathrm{Fe}, \mathrm{K}, \mathrm{S}$ and Ti (Haschke 2010 private information). It is worth pointing out that X-ray single crystal diffractometry performed for the selected solid state inclusions from blue halite crystals led us to distinguish mineral phases such as sylvite, carnallite, othorhombic sulfur, quartz, anhydrite, polyhalite and pyrite (Stadnicka and Zelek 2008). Additionally, in halite matrix, the trace amount of $\mathrm{K}, \mathrm{Mg}$ and $\mathrm{Cu}$ ( $0.25 \mathrm{ppm}$ in navy blue, pale blue and purple halite, and $0.42 \mathrm{ppm}$ in natural colourless halite) were detected by atomic absorption spectrometry (AAS) method (Reczyński, 2005 and 2011 , private information), and the trace amount of $\mathrm{Cu}(0.33-$ $0.44 \mathrm{ppm}$ ) was confirmed by anodic stripping voltametry (ASV) method (Baś, 2011, private information).

\section{UV-vis and Raman spectroscopy}

Typical absorption spectra for navy blue (A), pale blue (B), purple (C) and natural colourless (D) halite are shown in Fig. 5a. In general, for navy blue samples, two distinct absorption bands were found, at 630 and $385 \mathrm{~nm}$. The spectra for pale blue halite samples had the characteristic absorption band at $610 \mathrm{~nm}$, whereas the band at $580 \mathrm{~nm}$ was typical for the purple samples. At the high-energy side of the main broad band, a weak band at about $380 \mathrm{~nm}$ has always been observed. It was worth noting that, among blue salt samples from Kłodawa Salt Mine, one could also find amber-coloured fragments. These fragments, while exposed to sunlight, showed an immediate colour change, at first from amber to grey followed by the development of blue hue after a few years (1-5) storage at ambient pressure and temperature ca. $5^{\circ} \mathrm{C}$.

For navy blue $\mathrm{NaCl}$ halite (samples $\mathrm{A}$ ) a very intensive Raman band (Fig. 5b), observed at about $200 \mathrm{~cm}^{-1}$, was successfully resolved into three constituents at 194, 219 and $254 \mathrm{~cm}^{-1}$. The similar band set (Fig. 5b) was also noticed for pale blue samples (B), while it was not seen for purple samples (C) as well as for natural colourless crystals (D). The bands
Fig. 3 Anisotropic zones in the blue halite single crystal observed using polarising microscopy: $\mathrm{PX}$ at 0 and $45^{\circ}$

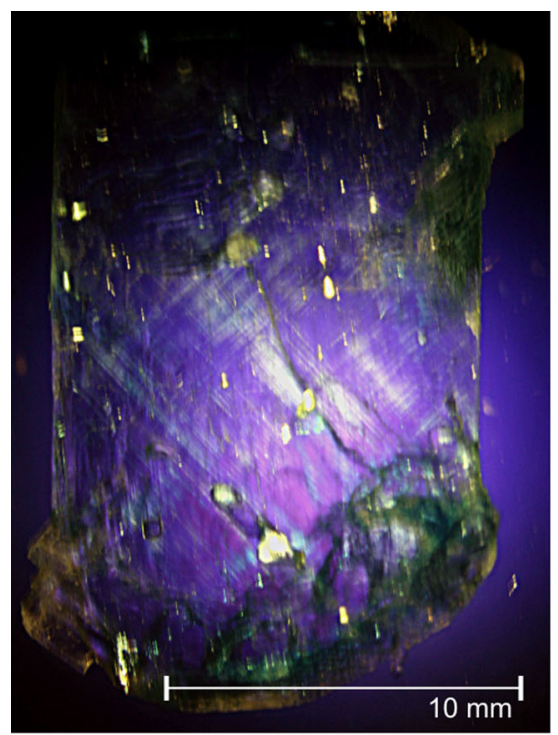

$\mathrm{PX}: 0^{\circ}$

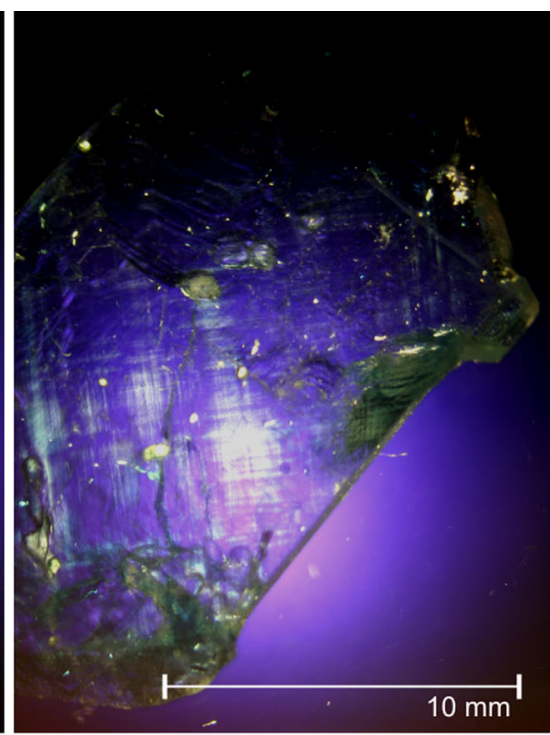

$\mathrm{PX}: 45^{\circ}$ 
Fig. 4 a Arrangement of blue colour in $0.5-\mathrm{mm}$ thick plate of halite (P1), S.I. denotes solid inclusions. b The same area between crossed polars $(P X)$ - the birefringence can be observed. c Aggregates of small, spherical solid inclusions in blue halite (thick plate, P1). d Large solid inclusions with irregular rounded shape (thick plate, $P 1$ )
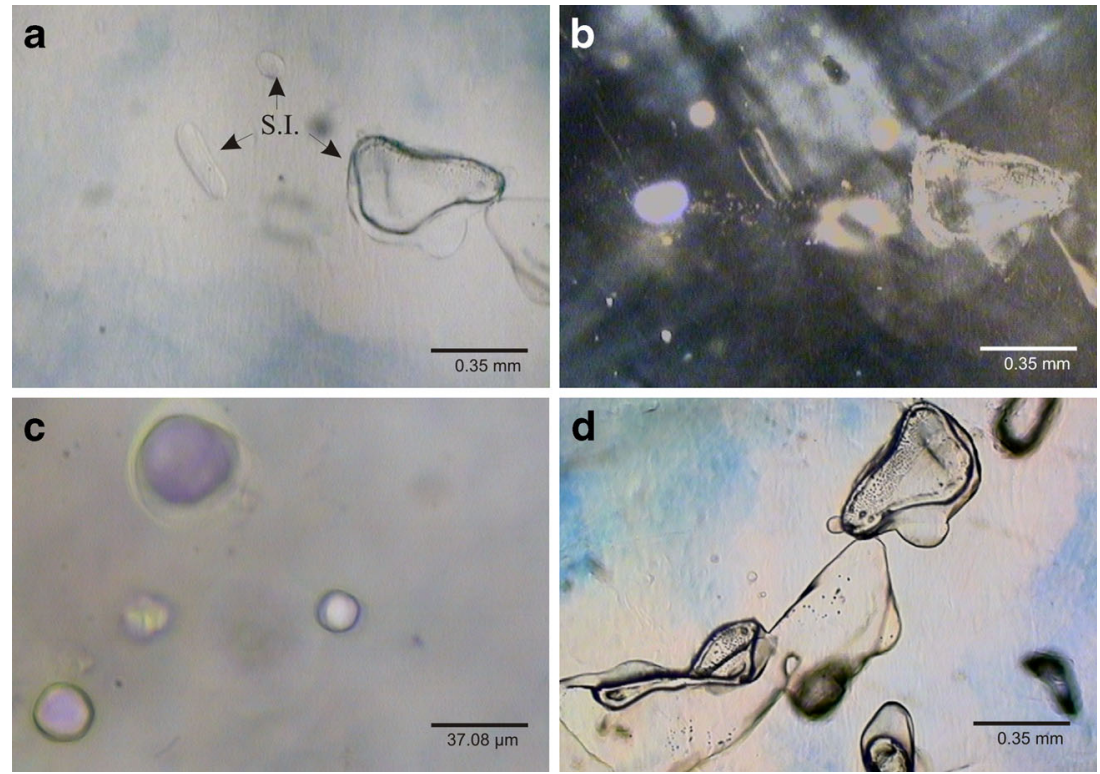

were destroyed while samples were heated from room temperature to $450{ }^{\circ} \mathrm{C}$.

\section{SEM-EDS investigations}

The samples for SEM-EDS data acquisition were separated from halite with different saturations of blue hue. Some examples of backscattered electron microscopy images of halite samples are presented in Fig. 6 (for other examples, see Toboła and Natkaniec-Nowak 2008). The concentration of other elements coexisting with sodium and chloride in halite samples as found from semiquantitative EDS analysis are given in Table 1. In all investigated samples, the main rock was determined as pure halite, whereas other phases were well separated in the forms of solid state inclusions. EDS of navy blue single

a

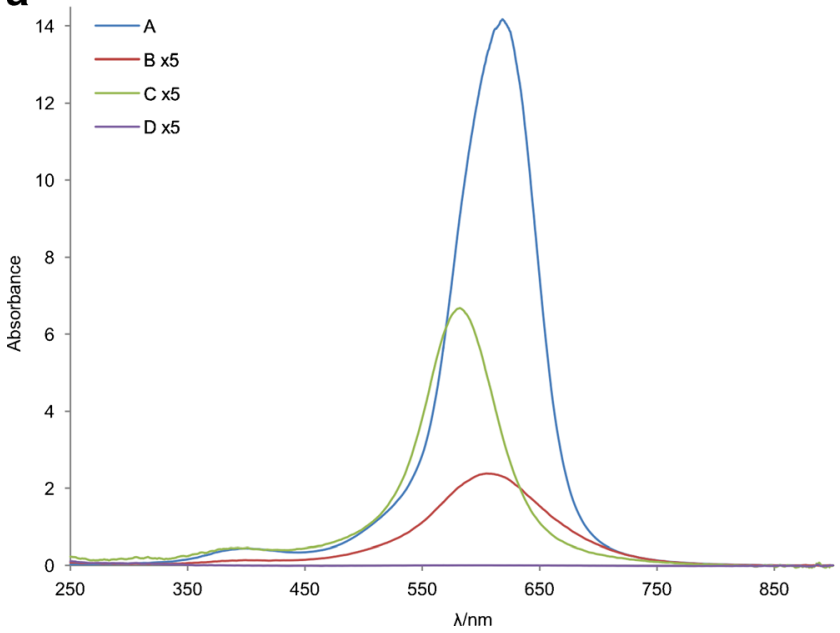

Fig. 5 a UV-vis spectra for halite samples from Kłodawa Salt Mine: navy blue $(A)$ - blue line, pale blue $(B)$ - red line, purple $(C)$ - green line and colourless $(D)$-violet line (the values for $B, C$ and $D$ were multiplied crystals from level $562 \mathrm{~m}$ indicated pure halite matrix $(\mathrm{NaCl})$ with $\mathrm{KCl}$ as solid state inclusions. It is worth noting that there is no difference between the composition of single crystal of blue halite and single crystal of natural colourless halite from the level $562 \mathrm{~m}$ except that the colourless halite contained more solid state inclusions with trace amounts of $\mathrm{K}, \mathrm{Mg}, \mathrm{Al}, \mathrm{Ca}, \mathrm{Fe}$ and $\mathrm{S}$, Si. The presence of $\mathrm{K}, \mathrm{Mg}, \mathrm{Cl}$ and $\mathrm{O}$ indicated carnallite. The source of $\mathrm{Fe}$ and $\mathrm{S}$ could be pyrite, whereas that of $\mathrm{Ca}$, $\mathrm{S}$ and $\mathrm{O}$ could be anhydrite. In addition to quartz, $\mathrm{Al}, \mathrm{Si}$ and $\mathrm{O}$, together with $\mathrm{K}, \mathrm{Ca}, \mathrm{Fe}$ and $\mathrm{Mg}$, could suggest the presence of some aluminosilicates. Oxygen accompanied $\mathrm{Na}, \mathrm{K}$ and $\mathrm{Cl}$ might be from the water molecules. Two-dimentional EDS elemental distribution maps for blue halite sample of Fig. $6 \mathrm{~b}$ from level $562 \mathrm{~m}$ revealed pure $\mathrm{NaCl}$ matrix and wellseparated $\mathrm{KCl}$ solid state inclusion (Fig. 7).

b

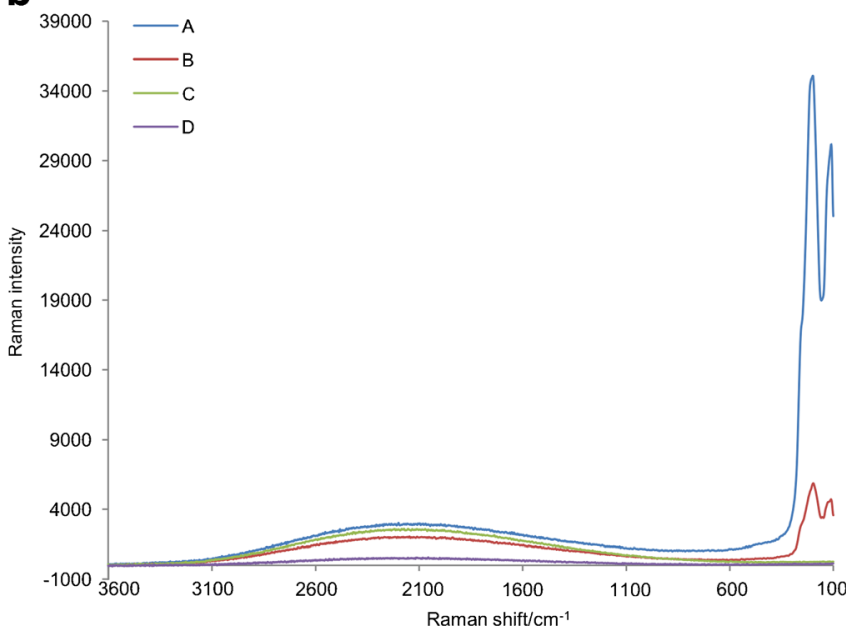

by 5 for the sake of clarity). $\mathbf{b} \mu$-Raman spectra for single-crystal samples $\mathrm{A}, \mathrm{B}, \mathrm{C}$ and D 
Fig. 6 Backscattered electron microscopy (BSE) images of halite single crystals containing: navy blue halite $(\mathbf{a}, \mathbf{b})$ from level $562 \mathrm{~m}$, colourless halite (d), and light blue (e, f) from level $750 \mathrm{~m}$. For navy blue halite from level $562 \mathrm{~m}$, secondary electron image (SE) is shown in c. Chemical analysis was performed for each point marked by cross (for other examples, see Toboła and Natkaniec-Nowak 2008)
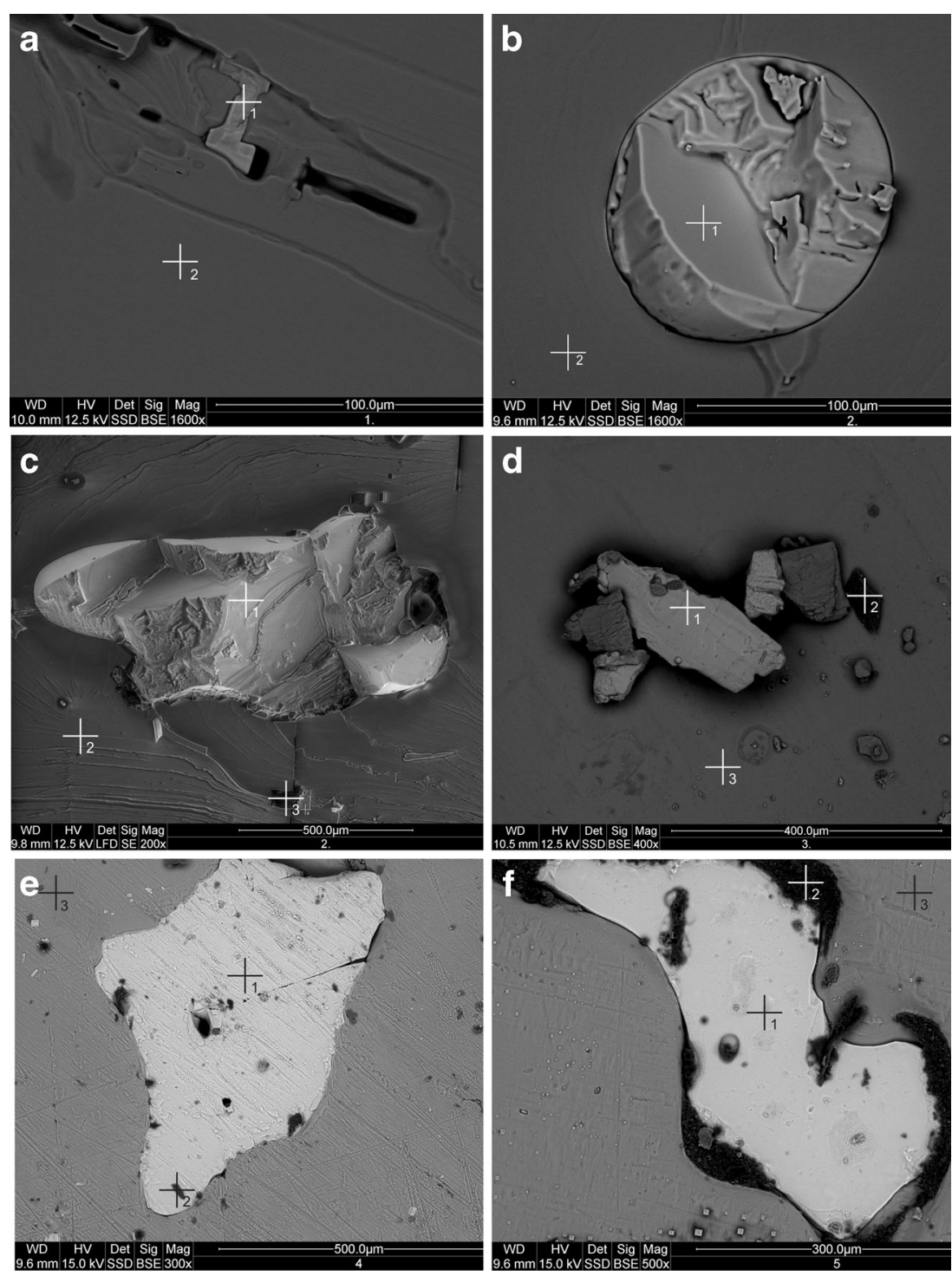

Single crystal X-ray diffraction for halite matrix

The analyses of crystallographic data, such as lattice parameters, unit-cell volume and various space group assignment were derived from the diffraction patterns. The results are given in Table 2 (data from KappaCCD diffractometer) and Table 3 (data from SuperNova diffractometer).

The intensity data collected with the KappaCCD diffractometer revealed significant deviations of intensity distribution from that characteristic for the cubic $\mathrm{NaCl}$ (Table 2). The halite samples of navy blue hue (A) predominantly showed the deformation of symmetry to monoclinic space group $C 2 / \mathrm{m}$, rarely to tetragonal one $(I 4 / \mathrm{mmm})$. For the samples of pale blue hue (B), the deformations to rhombohedral $R-3 m$ (for crystals with greenish blue shade) and to orthorhombic Fmmm or Immm space group (for crystals with light blue shade) were typical except for one case of monoclinic deformation for the sample B2 originating from level $750 \mathrm{~m}$. In the purple samples (C), cubic space group $\mathrm{Fm}-3 \mathrm{~m}$ was usually preserved.

Single crystal X-ray diffraction for solid inclusions in halite matrix

The selection of single crystals of solid inclusions found in different types of halite $(\mathrm{A}-\mathrm{C})$ was done with polarising microscopy. X-ray diffraction measurements using monochromated $\mathrm{MoK} \alpha$ radiation were performed only for those single crystals that were stable in ambient conditions after their isolation from inclusions. The crystallographic data for identified phases are listed in Table S1. The crystal structures of solid state inclusions were solved using SIR92 (Altomare et al. 1994). Tables S2 presents residual factors obtained during refinement procedure (SHELXL97, Sheldrick 2008). 
Table 1 Element concentration (at.\%) from EDS analysis for halite samples from Kłodawa Salt Mine

\begin{tabular}{|c|c|c|c|c|c|c|c|c|c|c|c|c|c|c|c|c|}
\hline \multirow{3}{*}{$\begin{array}{l}\text { Elements } \\
\text { Samples } \\
\text { Point }\end{array}$} & \multicolumn{16}{|l|}{ At. $\%$} \\
\hline & \multicolumn{2}{|l|}{ A } & \multicolumn{2}{|l|}{ B } & \multicolumn{3}{|l|}{$\mathrm{C}$} & \multicolumn{3}{|l|}{$\mathrm{D}$} & \multicolumn{3}{|l|}{$\mathrm{E}$} & \multicolumn{3}{|l|}{$\mathrm{F}$} \\
\hline & 1 & 2 & 1 & 2 & 1 & 2 & 3 & 1 & 2 & 3 & 1 & 2 & 3 & 1 & 2 & 3 \\
\hline $\mathrm{Na}$ & 28.81 & 48.55 & 21.95 & 49.70 & 9.98 & 48.21 & 16.05 & 18.06 & 30.51 & 48.49 & 8.90 & 13.34 & 50.26 & 12.15 & 25.14 & 49.26 \\
\hline $\mathrm{K}$ & 20.21 & - & 29.28 & 0.50 & 37.24 & 0.86 & 5.90 & 31.47 & 1.84 & 0.54 & 39.23 & 25.16 & 0.89 & 33.96 & 5.03 & 0.67 \\
\hline $\mathrm{Ca}$ & - & 0.32 & - & - & - & - & - & - & 2.84 & - & - & - & - & - & 1.44 & - \\
\hline $\mathrm{Al}$ & - & - & - & - & - & - & - & - & 2.27 & - & - & - & - & - & 14.03 & - \\
\hline $\mathrm{Si}$ & - & - & - & - & - & - & - & - & 12.55 & - & - & - & - & - & 0.23 & - \\
\hline $\mathrm{Fe}$ & - & - & - & - & - & - & - & - & 2.38 & - & - & - & - & - & - & - \\
\hline $\mathrm{Mg}$ & - & - & - & - & 0.44 & 0.31 & 8.51 & - & 0.66 & - & - & 2.15 & - & - & - & - \\
\hline $\mathrm{Cl}$ & 49.56 & 50.01 & 48.77 & 49.80 & 48.30 & 49.36 & 30.76 & 50.47 & 30.52 & 48.90 & 46.28 & 35.23 & 46.35 & 46.29 & 28.94 & 47.80 \\
\hline $\mathrm{O}$ & 1.42 & 1.13 & - & - & 4.04 & 1.26 & 38.78 & - & 15.40 & 2.07 & 5.59 & 24.13 & 2.51 & 7.60 & 23.96 & 2.28 \\
\hline $\mathrm{S}$ & - & - & - & - & - & - & - & - & 1.03 & - & - & - & - & - & 1.24 & - \\
\hline Total & 100 & 100.01 & 100 & 100 & 100 & 100 & 100 & 100 & 100 & 100 & 100 & 100.01 & 100.01 & 100 & 100.01 & 100.01 \\
\hline
\end{tabular}

Standardless ZAF corrections for semi-quantitative element normalised data were used

\section{Discussion}

The halite single crystals from Kłodawa Salt Mine, both with blue hue and colourless ones, indicated optical anisotropy. All birefringent fragments were found in the halite crystals of pronounced cleavage. According to Shlichta (1968), the birefringence could be considered as a result of stress and mechanical deformations of halite beds. Most of the mineral phases of the solid inclusions in dark blue halite were characterised by corrosion of their borders and changes in optical properties resulting from the secondary alterations of rocks (Heflik et al.
2008). It is worth noting that, around colourless solid-state inclusions in blue halites, there was usually observed colourless surrounding in close vicinity of the inclusion, whereas around blue halite inclusion in colourless matrix the close surrounding was blue (compare Figs. 2, 3 and 4).

The results of chemical composition analyses indicated that the blue halite samples consist of pure $\mathrm{NaCl}$, whereas the source of trace amounts of other elements are the inclusions. Despite of the investigation of gaseous and liquid inclusions in the halite from Kłodawa Salt Mine by Raman spectroscopy, which was published recently by Wesełucha-Birczyńska et al.
Fig. 7 Examples of EDS elemental distribution maps for blue halite single crystals from level $562 \mathrm{~m}$ containing rounded small solid inclusions presented in the Fig. $6 \mathrm{~b}$
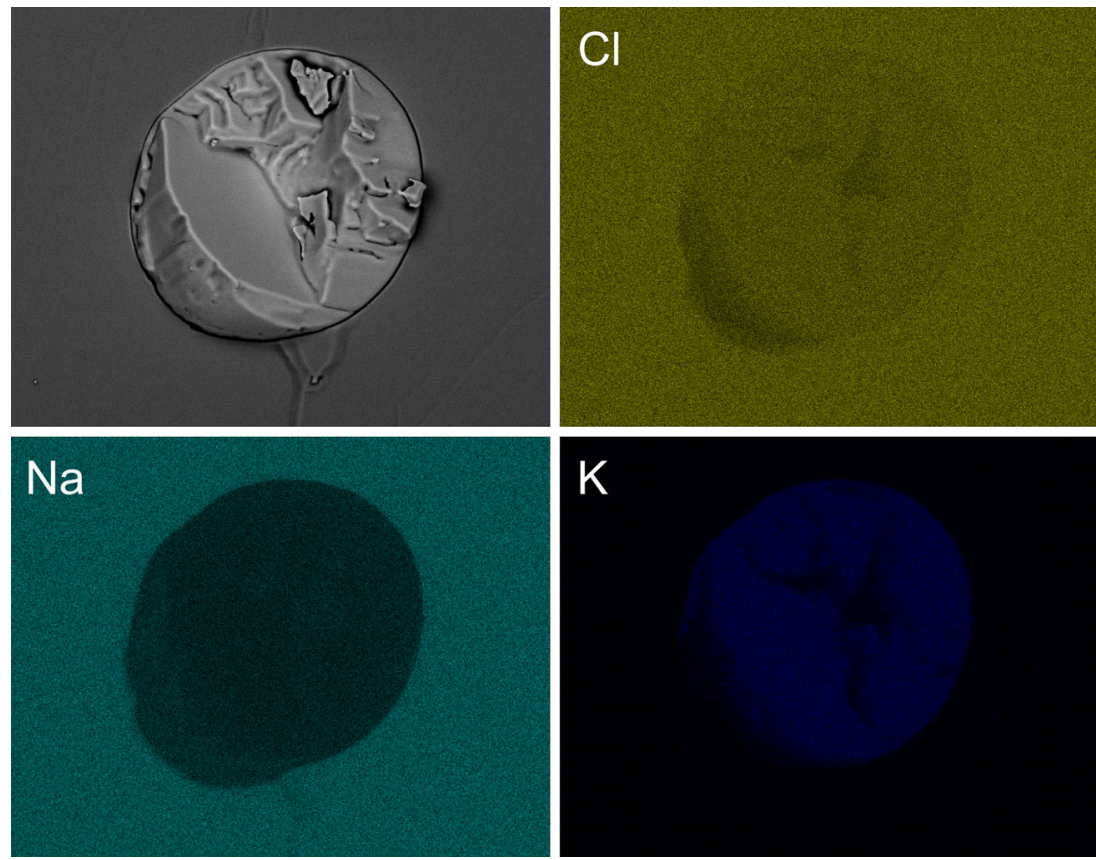
Table 2 Space group symmetry and lattice parameters for representative samples of halite from Kłodawa Salt Mine

\begin{tabular}{|c|c|c|c|c|c|c|c|c|c|c|c|}
\hline $\begin{array}{l}\text { Single-crystal } \\
\text { fragment }\end{array}$ & $\begin{array}{l}\text { Preliminary } \\
\text { space group }\end{array}$ & $\theta_{\max }$ & $\begin{array}{l}\text { Space } \\
\text { group* }\end{array}$ & $\begin{array}{l}\text { Number } \\
\text { of unique } \\
\text { reflections }\end{array}$ & $a(\AA)$ & $b(\AA)$ & $c(\AA)$ & $\alpha\left(^{\circ}\right)$ & $\beta\left({ }^{\circ}\right)$ & $\gamma\left({ }^{\circ}\right)$ & $V_{\text {k.el }}\left(\AA^{3}\right)$ \\
\hline $\mathrm{A} 1_{1}$-navy blue & $I 2 / m$ & 34.35 & $F m-3 m^{\mathrm{a}}$ & 35 & $5.6373(4)$ & $5.6384(2)$ & $5.6384(2)$ & $90.022(4)$ & $89.894(4)$ & $89.894(4)$ & $179.22(2)$ \\
\hline $\mathrm{A}_{2}{ }_{2}$ colourless & $F m-3 m$ & 34.31 & $F m-3 m$ & 35 & $5.6384(3)$ & $5.6384(3)$ & $5.6384(3)$ & 90.000 & 90.000 & 90.000 & $179.25(2)$ \\
\hline $\mathrm{A}_{3}$ —navy blue & $\mathrm{I} / \mathrm{mmm}$ & 36.22 & $F m-3 m^{\mathrm{a}}$ & 39 & $5.6415(3)$ & $5.6421(2)$ & $5.6421(2)$ & 90.000 & 90.000 & 90.000 & $179.59(1)$ \\
\hline $\mathrm{A}_{4}$ —navy blue & $C 2$ & 38.16 & $F 23^{\mathrm{b}}$ & 89 & $5.6350(2)$ & $5.6350(9)$ & $5.6350(9)$ & 90.000 & $90.000(9)$ & 90.000 & $178.90(6)$ \\
\hline $\mathrm{A} 2_{1}$-navy blue & $C 2 / m$ & 34.97 & $F m-3 m$ & 35 & $5.6410(3)$ & $5.6406(4)$ & $5.6410(3)$ & $89.995(5)$ & $90.023(6)$ & $90.005(6)$ & $179.49(6)$ \\
\hline $\mathrm{A} 2_{2}-$ colourless $^{\mathrm{c}}$ & $F m-3 m$ & 35.27 & $F m-3 m$ & 38 & $5.6408(3)$ & $5.6408(3)$ & $5.6408(3)$ & 90.000 & 90.000 & 90.000 & $179.48(3)$ \\
\hline B1-blue & Fmmm & 34.31 & Fmmm & 121 & $5.6382(3)$ & $5.6394(3)$ & $5.6522(3)$ & 90.000 & 90.000 & 90.000 & $179.72(2)$ \\
\hline B2-blue & $C 2 / m$ & 25.03 & $F m-3 m$ & 22 & $5.6639(4)$ & $5.6649(3)$ & $5.6649(3)$ & $90.181(6)$ & $90.234(6)$ & $90.234(6)$ & $181.76(4)$ \\
\hline $\mathrm{C} 1$ - purple & $F m-3 m$ & 34.29 & $F m-3 m$ & 35 & $5.6415(2)$ & $5.6415(2)$ & $5.6415(2)$ & 90.000 & 90.000 & 90.000 & $179.55(1)$ \\
\hline C2-purple & $F m-3 m$ & 35.25 & $F m-3 m$ & 37 & $5.6435(4)$ & $5.6435(4)$ & $5.6435(6)$ & 90.000 & 90.000 & 90.000 & $179.74(3)$ \\
\hline D1—colourless & $F m-3 m$ & 34.29 & $F m-3 m$ & 35 & $5.6416(2)$ & $5.6416(2)$ & $5.6416(2)$ & 90.000 & 90.000 & 90.000 & $179.56(1)$ \\
\hline D2-colourless & $C 2 / m$ & 33.04 & $F m-3 m$ & 33 & $5.6440(2)$ & $5.6440(2)$ & $5.6440(2)$ & 90.000 & $90.000(10)$ & 90.000 & $179.8(1)$ \\
\hline
\end{tabular}

Diffractometer Nonius KappaCCD, $20{ }^{\circ} \mathrm{C}, \lambda(\mathrm{MoK} \alpha)=0.71073 \AA(55 \mathrm{kV}, 30 \mathrm{~mA})$

${ }^{\text {a }}$ Space group $F m$-3m imposed, calculations using the program Platon (Spek 2009)

${ }^{\mathrm{b}}$ Refinement on $\mathrm{Fm}-3 m$ and $\mathrm{Fm}$-3 unstable

${ }^{\mathrm{c}}$ After the recrystallization of the navy blue fragment of sample A1 from aqueous solution

(2008), there are many solid state inclusions in the form of single crystals.

Two distinct absorption bands at 630 and $385 \mathrm{~nm}$ observed for navy blue halite are responsible for superimposed complementary colours: blue and yellowish green, respectively. The characteristic absorption band at $610 \mathrm{~nm}$ for pale blue halite samples is responsible for clear blue colour, and the band at $580 \mathrm{~nm}$ for the purple colour. The findings are consistent with the earlier work by Zelek et al. (2008). Similar spectroscopic properties were also observed for Stassfurt blue halite samples (also Zechstein deposit) by Phipps and Brode as early as in 1926. The blue hue of halites is due to the colour centre aggregates. The centres were identified as: $F, R_{1}\left(F_{3}\right), R_{2}$ $\left(\mathrm{F}_{3}\right)$ bands, plasmon band and M-band. The populations of these colour centres were recently estimated by WeseluchaBirczyńska et al. (2012). Usually in the studied samples, the dispersed discrete F-centres with characteristic band at
$465 \mathrm{~nm}$ (compare Howard and Kerr 1960) display very low population. The detailed interpretation of the colour centres behaviour under heating is going to be published elsewhere.

The observed Raman spectra with the bands in the region $100-300 \mathrm{~cm}^{-1}\left(194,219\right.$ and $254 \mathrm{~cm}^{-1}$, acc. WeseluchaBirczyńska et al. 2012) confirmed the presence of colour centres and also metal colloid particles in the studied halite samples. The bands were destroyed while samples were heated, which indicated the appropriate assignment of the bands.

The diffraction results obtained with a KappaCCD diffractometer prompt us to constrain the experimental data to the ideal structure (six $\mathrm{Cl}^{-}$ions in the corners of $\mathrm{Na}^{+}$octahedron and vice versa) and to space group $F m-3 m$ typical for pure, perfect $\mathrm{NaCl}$. In this procedure, the intensities which failed to fulfil $F m$-3m space-group conditions were omitted and averaged lattice parameters were compared to those obtained from measurements performed with SuperNova diffractometer.

Table 3 Space group symmetry and lattice parameters for representative samples of halite from Kłodawa Salt Mine

\begin{tabular}{|c|c|c|c|c|c|c|c|c|c|c|}
\hline $\begin{array}{l}\text { Single-crystal } \\
\text { fragment }\end{array}$ & Space group & $\theta_{\max }$ & $\begin{array}{l}\text { Number of } \\
\text { reflections }\end{array}$ & $a(\AA)$ & $b(\AA)$ & $c(\AA)$ & $\alpha\left(^{\circ}\right)$ & $\beta\left({ }^{\circ}\right)$ & $\gamma\left({ }^{\circ}\right)$ & $V_{\text {k.el }}\left(\AA^{3}\right)$ \\
\hline A3 - navy blue & $F m-3 m$ & 40.65 & 50 & $5.6469(2)$ & $5.6444(2)$ & $5.6442(2)$ & $90.022(3)$ & $90.027(3)$ & $90.009(3)$ & $179.90(1)$ \\
\hline A4 navy blue & $F m-3 m$ & 40.57 & 48 & $5.6520(3)$ & $5.6512(4)$ & $5.6524(4)$ & $90.018(5)$ & $90.013(5)$ & $89.993(5)$ & $180.54(2)$ \\
\hline A5-navy blue & $F m-3 m$ & 40.64 & 45 & $5.6434(8)$ & $5.6364(8)$ & $5.6440(8)$ & $90.081(12)$ & $899.71(11)$ & $89.983(11)$ & $179.53(4)$ \\
\hline B3-blue & $F m-3 m$ & 40.65 & 49 & $5.6422(3)$ & $5.6420(3)$ & $5.6424(2)$ & $90.020(4)$ & $90.001(4)$ & $90.003(4)$ & $179.62(2)$ \\
\hline C3-purple & $F m-3 m$ & 45.42 & 59 & $5.6453(2)$ & $5.6454(2)$ & $5.6446(2)$ & $90.010(3)$ & $89.995(3)$ & $90.025(3)$ & $179.89(1)$ \\
\hline D3 - colourless & $F m-3 m$ & 40.85 & 51 & $5.6500(2)$ & $5.6498(2)$ & $5.6454(3)$ & $90.022(4)$ & $90.015(4)$ & $89.980(4)$ & $180.21(1)$ \\
\hline
\end{tabular}

Diffractometer Agilent Technologies SuperNova, $25^{\circ} \mathrm{C}, \lambda(\mathrm{MoK} \alpha)=0.71073 \AA$ (50 kV, $\left.0.80 \mathrm{~mA}\right)$ 
Table 4 Lattice parameters of synthetic solid solution $\mathrm{K}_{x} \mathrm{Na}_{1-x} \mathrm{Cl}$ taken from PDF-2 database (Faber and Fawcett 2002) and used for the derivation of relationship between the lattice parameters and chemical compositions: $y=0.6513 x+5.6407\left(R^{2}=1\right)$

\begin{tabular}{lll}
\hline Synthetic solid solution & $x$ & $a(\AA)$ \\
\hline $\mathrm{NaCl}$ & 0 & 5.6402 \\
$\mathrm{~K}_{x} \mathrm{Na}_{1-x} \mathrm{Cl}$ & 0.2 & 5.7712 \\
$\mathrm{~K}_{x} \mathrm{Na}_{1-x} \mathrm{Cl}$ & 0.4 & 5.9018 \\
$\mathrm{KCl}$ & 1 & 6.2917
\end{tabular}

The averaged lattice parameters were then used to estimate the potassium contents in blue halite samples. For several samples (B1, C2, D2, C3, A3, D3, A4 and B2), despite their various characteristic hue, significant enlargement of lattice parameters was observed when compared to the value typical for the colourless one, i.e. $a=5.6408(3) \AA$ found for $\mathrm{A} 22_{2}$ crystals obtained through the recrystallisation of the navy blue A1 sample from aqueous solution. The enlargement of lattice parameters might indicate the presence of small contents of potassium ions in these crystals. For some samples, e.g. $\mathrm{A} 1_{2}$ and $\mathrm{A} 1_{4}$ (navy blue) or $\mathrm{A} 1_{1}$ (a natural colourless part of A1), the significant contraction of lattice parameters was observed, when compared to $a=$
$5.6408(3) \AA$. The presence of vacancies could be considered as a reason of the contraction. For the purpose of the estimation of potassium contents, a relationship between the values of cubic lattice parameter and possible chemical composition was derived assuming the formation of $\mathrm{KCl} / \mathrm{NaCl}$ solid solution and using the literature data for synthetic $\mathrm{K}_{x} \mathrm{Na}_{(1-x)} \mathrm{Cl}$, where $x=0.0$, $0.2,0.4$ and 1.0 (PDF-2 database, Faber and Fawcett 2002). The lattice parameters determined for the solid solutions are given in Table 4. The equation obtained was then applied to the averaged lattice parameters of the studied samples (Fig. 8), indicating the highest potassium contents in the pale blue sample B2 $(x=$ 0.0366). The relatively high potassium contents were also found for the pale blue sample B1 $(x=0.0039)$, in which it was similar to the value of 3,024 ppm obtained by AAS method for the pale blue sample B 8 (Reczyński, 2005 and 2011, private information).

The solid state inclusions identified by single-crystal diffraction methods were the following: those isolated from the navy blue halite of type A were found to be sylvine $(\mathrm{KCl})$, orthorhombic sulphur $\left(\mathrm{S}_{8}\right)$ and $\alpha$-quartz $\left(\alpha-\mathrm{SiO}_{2}\right)$; for the pale blue halite of type $\mathrm{B}$, mainly carnallite $\left(\mathrm{KMgCl}_{3} \cdot 6 \mathrm{H}_{2} \mathrm{O}\right)$ was identified, and the most common solid inclusions in the halite type $\mathrm{C}$ were pyrite $\left(\mathrm{FeS}_{2}\right)$ and carnallite.

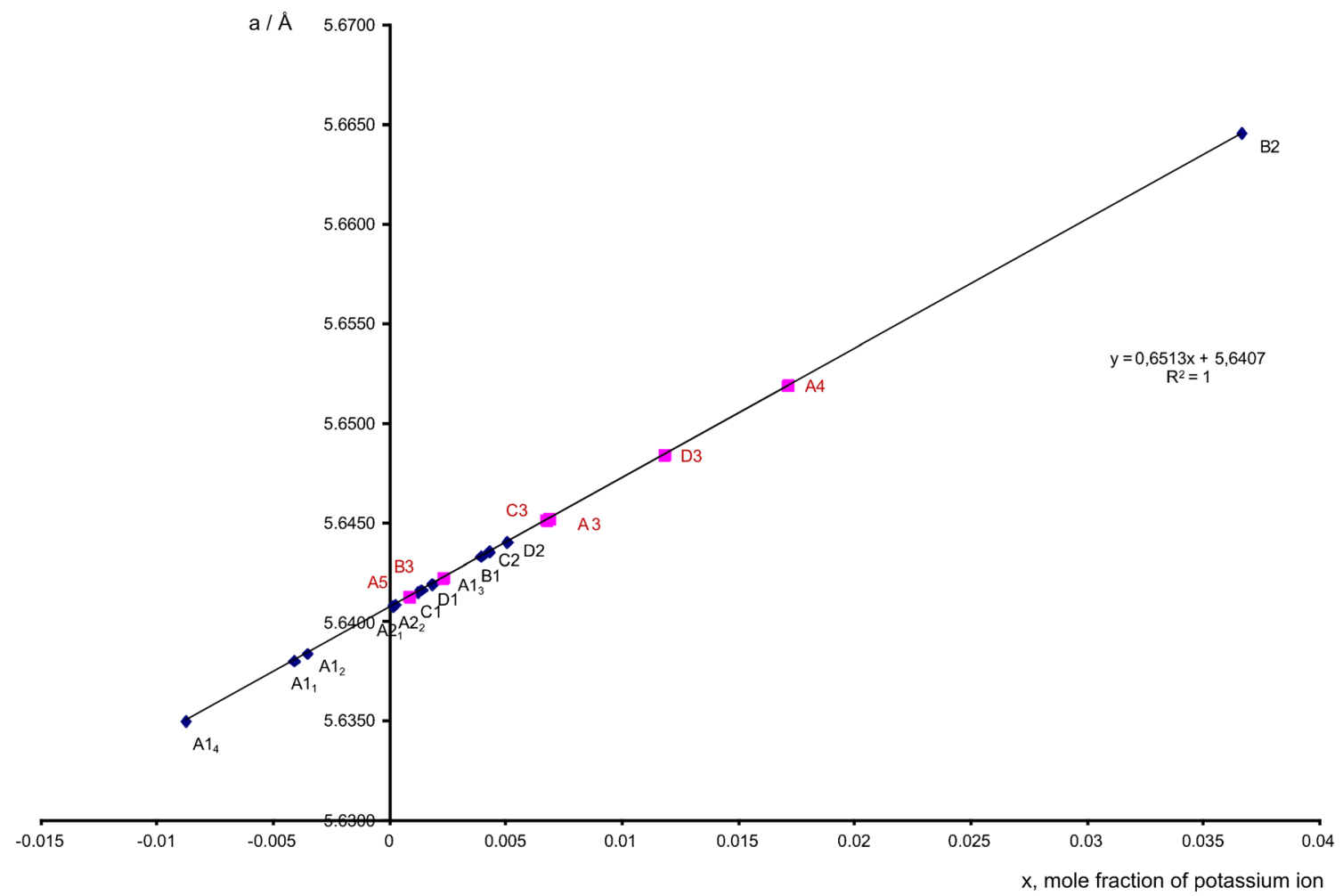

Fig. 8 Lattice parameters versus chemical composition parameter $x$ for single crystals of halite from Kłodawa Salt Mine assuming solid solution $\mathrm{K}_{x} \mathrm{Na}_{(1-x)} \mathrm{Cl}$ (the line represents the relationship according to Table 4).
The sample numbering is consistent with that used in Table 2 (marked by navy blue diamonds) and Table 3 (marked by pink squares) 


\section{Conclusions}

Fieldwork observations carried out in Kłodawa Salt Mine indicated that blue halite occurrence was mainly connected with the epigenetic sediments, such as sylvinite rich in potassium. The high contents of potassium-40 could be considered as the source of gamma-ray necessary for the production of scattered F-centres (compare Howard and Kerr 1960). In particular thermodynamic conditions, the dispersed F-centres might possibly aggregate. The formation of such aggregates (F-centre clusters) was pointed out by Farge and Fontana (1979), Georgiev (1988) and also by Seinen et al. (1994a). It should be emphasised that the chemical impurities are not responsible for the blue colouration of the halites.

The presence of epigenetic sediments does not always guarantee the occurrence of blue halite, though the co-occurrence of blue halite with the primary potassium-magnesium salts, such as carnallite and polyhalite, was rarely observed. Additionally, the blue halite associations together with the epigenetic sediments were related to tectonites (Sonnenfeld 1995; Davidge and Pratt 1963). The tectonic deformation of the salt strata observed in macroscopic scale has been manifested in microscopic scale as a specific birefringence in thin samples not only of blue halite but also of natural colourless halite from the Kłodawa Salt Mine. The influence of geological environment seems to be a significant condition for the formation and stabilisation of blue halite deposits.

From single crystal X-ray diffraction study of the blue halites, it could be concluded that, in Kłodawa Salt Mine, not only halite beds are highly deformed but also the crystal structure of blue halite is deformed at atomic level. The deformation degree of the blue halite structure from that characteristic for the pure cubic $\mathrm{NaCl}$ could be roughly correlated with the observed hue of the blue colour which is a result of a particular colour centre aggregation.

In our opinion, the clusters of various types of colour centres seem to be stabilised by different sort of already existing lattice defects. The size of colour centre clusters and the type of structure deformation at atomic level would have an effect on the stabilisation of the whole system and thus could be regarded as responsible for the observed variety of absorption bands and consequently for stable, at ambient conditions, blue and/or purple hue of the halites from the Kłodawa Salt Mine.

Main deformation mechanism under the stress conditions concerned dislocation creep and some processes of static recrystalisation, which however did not eliminate the primary numerous defects (such as dislocation debris) in halite crystals (compare Schléder et al. 2007). After irradiation, the discrete F-centres should be randomly distributed in halite crystals; however, the deformed crystals contain defects that can act as electron traps and assist clustering processes of colour centres (Davidge and Pratt 1963). The clusters of colour centres are stabilised at the defects.
Our conclusions seems to be consistent with the results of the analysis of microstructures in halite samples from the Kłodawa Salt Mine published recently by Schléder et al. (2007) but different, to some extent, from the statement by Howard and Kerr (1960) that the gamma-ray irradiation is exclusively causing the deformation of the halite.

The main issue derived from the experiments performed concerning the generation of the colour centre clusters and their stabilisation by structural deformation still remains to be verified. In the future, it would be necessary to find a qualitative relationship between the hue of halite and the size of colour centre clusters, in order to consider the influence of the energy and intensity of isotope radiation on the type of the produced single, scattered colour F-centres, and to discuss the possibility of colour centres aggregation along with the degree of structure deformations of the halite from the Kłodawa Salt Mine.

Acknowledgements Authors thank: Dr. Krzysztof Kozak from Natural Radioactivity Laboratory, The Henryk Niewodniczański Institute of Nuclear Physics, Polish Academy of Sciences; Dr. Michael Haschke from Bruker Nano GmbH Germany for $\mu$-XRF analysis; Dr. Witold Reczyński from Department of Analytical Chemistry, Faculty of Materials Science and Ceramics, AGH University of Science and Technology for AAS analysis; Dr. Bogusław Baś Department of Analytical Chemistry, Faculty of Materials Science and Ceramics, AGH University of Science and Technology for ASV analysis; and the X-ray Laboratory, Faculty of Chemistry, Jagiellonian University for making the Bruker-Nonius KappaCCD diffractometer available. The research was also carried out with the equipment (Agilent Technologies SuperNova ) purchased thanks to the financial support of the European Regional Development Found in the framework of the Polish Innovation Economy Operational Program (contract no. POIG.02.00-12-023/08).

Open Access This article is distributed under the terms of the Creative Commons Attribution License which permits any use, distribution, and reproduction in any medium, provided the original author(s) and the source are credited.

\section{References}

Altomare A, Cascarano G, Giacovazzo C, Guagliardi A, Burla MC, Polidori G, Camalli M (1994) SIR92 - a program for automatic solution of crystal structures by direct methods. J Appl Crystallogr 27:435. doi:10.1107/S002188989400021X

Burliga S, Kolonko P, Misiek G, Czapowski G (1995) Kłodawa Salt Mine. In: Maliszewska A, Wagner R (eds) Upper Rotliegend-Zechstein: terrestrial-marine sedimentary succession in Polish Permian Basin. XIII International Congress on Carboniferous-Permian, August 28 September 2, 1995; Guide to Excursion A3, Kraków, Poland, pp 45-54

Charysz W (1973) Zechstein stage of younger salts (Z3) in Kujawy region (in Polish with English summary). Pr Geol 75:7-66

Dadlez R (2003) Mesozoic thickness pattern in the Mid-Polish Trough. Geol Q 47:223-240

Dadlez R, Narkiewicz M, Stephenson RA, Visser MTM, van Wees J-D (1995) Tectonic evolution of the Mid-Polish Trough: modelling implications and significance for central European geology. Tectonophysics 252:179-195. doi:10.1016/ 0040-1951(95)00104-2 
Davidge RW, Pratt PL (1963) Formation of colour centres in undeformed and deformed NaCl. Phys Status Solidi B 3:665-670. doi:10.1002/ pssb.19630030409

den Hartog HW (1999) Stored energy of heavily irradiated NaCl. Radiat Eff Defects 150(1):167-172. doi:10.1080/01418617908239295

den Hartog HW, Vainshtein DI (1997) Explosive phenomena in heavily irradiated NaCl. Mater Sci Forum 239-241(1):611-614. doi:10. 1088/0957-0233/2/12/013

den Hartog HW, Vainshtein DI, Dubinko VI, Turkin AA (2002) New scenario for the accumulation and release of radiation damage in rock salt and related materials. Nucl Instrum Meth B 191(1):168172. doi:10.1016/S0168-583X(02)00548-7

den Hartog HW, Sugonyako AV, Vainshtein DI, Turkin AA, Sulyanov SN, Kheiker DM, Dorovatovskii PV (2007) Characterization of ultra-heavily damaged NaCl. Phys Status Solidi C 4(3):10791083. doi: $10.1002 /$ pssc. 200673768

Faber J, Fawcett T (2002) The powder diffraction file: present and future. Acta Crystallogr B 58:325-332. doi:10.1107/S0108768102003312

Farge Y, Fontana MP (1979) Electronic and vibrational properties of point defects in ionic crystals. North-Holland Publishing Company, Amsterdam

Garlicki A (1993) On some trace elements of Zechstein younger salts in Poland. In: 7th Symposium on Salt: Proceedings of the Seventh International Symposium on Salt, Kyoto, Japan, 6-9 April, 1992, Vol. I, Elsevier Publishers B.V., Amsterdam, pp 165-170

Garlicki A, Szybist A (1986) Saline deposits of Polish Zechstein with potash salts (in Polish with English summary). Miner Resour Manag IGSMiE PAN 2(3/4):389-404

Garlicki A, Szybist A (1991) Trace elements in salts of Kłodawa Salt Mine (in Polish with English summary). Miner Spec Pap 1:71-76

Garlicki A, Szybist A (2008) Geological structure of Kłodawa Salt Dome. In: Toboła T, Natkaniec-Nowak L (eds) Blue halite of the Kłodawa Salt Dome (in Polish with English summary). AGH University of Science and Technology Press, Kraków, pp 13-23

Georgiev M (1988) F' centers in alkali halides, lecture notes in physics. Springer, Berlin

Groote JC, Weerkamp JRW, den Hartog HW (1991a) An irradiation facility for radiation damage investigations. Meas Sci Technol 2(12):1187-1191. doi:10.1088/0957-0233/2/12/013

Groote JC, Seinen J, Weerkamp JRW, den Hartog HW (1991b) Radiation damage in $\mathrm{NaCl}$. Experiment and analysis. Radiat Eff Defects 119 121(2):925-930. doi:10.1080/10420159108220844

Groote JC, Weerkamp JRW, Seinen J, den Hartog HW (1994) Radiation damage in NaCl. IV. Raman scattering. Phys Rev B 50(14):97989802. doi:10.1103/PhysRevB.50.9798

Heflik W, Natkaniec-Nowak L, Toboła T (2008) Microscopic investigation of blue salts. In: Toboła T, Natkaniec-Nowak L (eds) Blue halite of the Kłodawa Salt Dome (in Polish with English summary). AGH University of Science and Technology Press, Kraków, pp 56-69

Howard CLH, Kerr PF (1960) Blue halite. Science 132(3443):18861887. doi:10.1002/pssb.19630030409

Janiów S, Misiek G, Toboła T, Natkaniec-Nowak L (2008) Blue salts in Kłodawa Salt Mine. In: Toboła T, Natkaniec-Nowak L (eds) Blue halite of the Kłodawa Salt Dome (in Polish with English summary). AGH University of Science and Technology Press, Kraków, pp 24 53

Krzywiec P (2004a) Triassic evolution of the Kłodawa salt structure: basement-controlled salt tectonics within the Mid-Polish Trough (Central Poland). Geol Q 48(2):123-134

Krzywiec P (2004b) Basement vs. salt tectonics and salt-sediment interaction - case study of the Mesozoic evolution of the Intercontinental Mid-Polish Trough. In: Post PJ, Olson DL, Lyons KT, Palmes SL, Harrison PF, Rosen NC (eds) Salt-sediment interactions and hydrocarbon prospectivity: concepts, applications and case studies for the 21st century. GCSSEPM Foundation 24th Annual Research Conference, 5-8 December 2004, pp 343-370
Krzywiec P (2006a) Triassic-Jurassic evolution of the Pomeranian segment of the Mid-Polish Trough - basement tectonics and subsidence patterns. Geol Q 50(1):139-150

Krzywiec P (2006b) Structural inversion of the Pomeranian and Kuiavian segments of the Mid-Polish Trough - lateral variations in timing and structural style. Geol Q 50(1):151-168

Krzywiec P, Kramarska R, Zientara P (2003) Strike-slip tectonics within the SW Baltic Sea and its relationship to the inversion of the Mid-Polish Trough - evidence from high-resolution seismic data. Tectonophysics 373:93-105. doi:10.1016/S00401951(03)00286-5

Marek S, Znosko J (1972a) Tectonics of the Kujawy Region (in Polish with English summary). Geol Q 16(1):1-18

Marek S, Znosko J (1972b) History of geological development of the Kujawy region (in Polish with English summary). Geol Q 16(2): 233-248

Natkaniec-Nowak L, Toboła T (2003) Blue salt from Kłodawa (in Polish with English summary). Pol Geol Rev 51(5):435-438

Ollier CD, Koziar J (2007) Why the plate tectonics rock cycles do not work? Pol Geol Rev 55(5):375-382

Phipps TE, Brode WR (1926) A comparative study of two kinds of colored rock salt. J Phys Chem-US 30(4):507-520. doi:10.1021/ j150262a007

Pokorski J, Wagner R (1995) Stratigraphy and development of the Polish Permian Basin. In: Maliszewska A, Wagner R (eds) Upper RotliegendZechstein: terrestrial-marine sedimentary succession in Polish Permian Basin, XIII International Congress on Carboniferous-Permian, August 28 - September 2, 1995; Guide to Excursion A3, Kraków, Poland, pp 7-22

Schléder Z, Burliga S, Urai JL (2007) Dynamic and static recrystallization-related microstructures in halite samples from the Kłodawa salt wall (central Poland) as revealed by gammairradiation. Neues Jb Miner - Abh 184(1):17-28. doi:10.1127/ 0077-7757/2007/0079

Seinen J, Groote JC, Weerkamp JRW, den Hartog HW (1992) Radiation damage in $\mathrm{NaCl}$ : general model of nucleation and aggregation processes in doped $\mathrm{NaCl}$. Radiat Eff Defects 124(3):325-339. doi: 10.1080/10420159208220205

Seinen J, Groote JC, Weerkamp JRW, den Hartog HW (1994a) Radiation damage in $\mathrm{NaCl}$. II. The early stage of F-center aggregation. Phys Rev B 50(14):9787-9792. doi:10.1103/PhysRevB.50.9787

Seinen J, Weerkamp JRW, Groote JC, den Hartog HW (1994b) Radiation damage in $\mathrm{NaCl}$. III. Melting phenomena of sodium colloids. Phys Rev B 50(14):9793-9797. doi:10.1103/ PhysRevB.50.9793

Sheldrick GM (2008) A short history of SHELX. Acta Crystallogr A 64: 112-122. doi:10.1107/S0108767307043930

Shlichta PJ (1968) Growth, deformation, and defect structure of salt crystals. In: Mattox RB (ed) Saline deposits. A symposium based on Papers from the International Conference on Saline Deposits, Houston, Texas, 1962. The Geological Society of America, INC. Special Paper 88, pp 587-617. doi:10.1130/ SPE88-p597

Sonnenfeld P (1995) The color of rock salt — a review. Sediment Geol 94: 267-276. doi:10.1016/0037-0738(94)00093-A

Spek AL (2009) Structure validation in chemical crystallography. Acta Crystallogr D 65:148-155. doi:10.1107/S090744490804362X

Stadnicka K, Zelek S (2008) Structural investigation of blue salts and solid state inclusions in halite. In: Toboła T, Natkaniec-Nowak L (eds) Blue halite of the Kłodawa Salt Dome (in Polish with English summary). AGH University of Science and Technology Press, Kraków, pp 100-123

Szybist A (1995) Geological cross-section through Kłodawa Salt Dome. Archive of the Department of Geology and Mining Faculty of Geology, Geophysics and Environmental Protection, AGH University of Science and Technology, Kraków 
Tarka R (1992) Tectonics of some salt deposits in Poland based on mesostructural analyses (in Polish with English summary). Prace PIG 137:1-47

Toboła T, Natkaniec-Nowak L (2008) SEM-EDS investigation of solid state inclusion. In: Toboła T, Natkaniec-Nowak L (eds) Blue halite of the Kłodawa Salt Dome (in Polish with English summary). AGH University of Science and Technology Press, Kraków, pp 70-80

Toboła T, Natkaniec-Nowak L, Szybist A, Misiek G, Janiów S (2007) Blue salts in Kłodawa Salt Mine (in Polish with English summary). Miner Res Manag IGSMiE PAN 23(1):117-132

Wagner R (1994) Stratigraphy and evolution of the Zechstein Basin in the Polish Lowland (in Polish with English summary). Prace PIG 146:5-71

Wagner R, Leszczyński K, Pokorski J, Gumulak K (2002) Palaeotectonic cross-sections through the Mid-Polish Trough. Geol Q 46(3):293-306

Weerkamp JRW, Groote JC, Seinen J, den Hartog HW (1994) Radiation damage in $\mathrm{NaCl}$. I. Optical-absorption experiments on heavily irradiated samples. Phys Rev B 50(14):9781-9786. doi:10.1103/ PhysRevB.50.9781
Werner Z, Poborski J, Orska J, Bąkowski J (1960) A geological and mining outline of the Kłodawa salt deposit (in Polish with English summary). Prace PIG 30(2):467-495

Wesełucha-Birczyńska A, Toboła T, Natkaniec-Nowak L (2008) Raman microscopy of inclusions in blue halites. Vib Spectrosc 48:302-307. doi:10.1016/j.vibspec.2008.05.005

Wesełucha-Birczyńska A, Zelek S, Stadnicka K (2012) Blue halite color center aggregates studied by micro Raman spectroscopy and X-ray diffraction. Vib Spectrosc 60:124-128. doi:10.1016/j.vibspec.2011. 11.001

Zelek S, Stadnicka K, Szklarzewicz J, Natkaniec-Nowak L, Toboła T (2008) Halite from Kłodawa: an attempt at correlation between the degree of crystal structure deformation and spectroscopic properties in UV-VIS range (in Polish with English summary). Miner Res Manag IGSMiE PAN 24(3/2):159-172

Ziegler PA (1990) Geological atlas of Western and Central Europe. Shell Internationale Petroleum, Maatschappij B.V. 